\title{
Editorial
}

\author{
Alexander Cotte Poveda* \\ Editor Revista CIFE \\ Universidad Santo Tomás
}

\section{Instituciones y calidad de la educación}

La importancia de las instituciones y la calidad de la educación son elementos centrales en la valoración de los conocimientos y las habilidades adquiridas por el capital humano en sus diferentes formas de expresión. La calidad de la educación está íntimamente relacionada con la institucionalidad y las reglas establecidas, información pertinente para determinar las competencias alcanzadas durante el proceso de formación. En este sentido, los criterios, la evaluación, el desempeño, los resultados, la productividad y la incidencia de otra serie de variables tienen efectos que se manifiestan en la generación de conocimiento y las responsabilidades que como bien público tiene la educación con calidad en la sociedad.

Una de las preguntas relevantes está íntimamente relacionada con la siguiente idea: ¿Cuáles son los criterios de calidad en la educación que determinan el desempeño de ese capital humano formado a lo largo del tiempo? La importancia de esta pregunta

* Editor de la Revista CIFE: Lecturas de Economía Social, de la Universidad Santo Tomás, Facultad de Economía. Dirección de correspondencia: Facultad de Economía, Universidad Santo Tomás, carrera 9 n. ${ }^{\circ}$ 51-11, piso 3, Bogotá, Colombia. Correos electrónicos: alexandercotte@usantotomas.edu.co y revicife@usantotomas.edu.co 
radica en que permite determinar y analizar los factores que afectan la calidad de la educación, sus posibles respuestas pueden permitir fortalecer los procesos académicos y potencializar resultados, desde estrategias diferenciadas, pero enfocadas en la calidad de la enseñanza-aprendizaje. El conocimiento de los factores que afectan el desempeño y la calidad entre otras variables permiten generar conocimiento relevante para la toma de decisiones de política en materia educativa, mejorar las prácticas docentes y académicas y promover una mayor equidad en términos de aprendizaje en los sistemas educativos y su institucionalidad.

El término de calidad está dado según el contexto en el cual se emplee, y es difícil llegar a un consenso sobre la conceptualización del término, para los académicos se refiere a los saberes, para los empleadores a competencias, para los estudiantes a la empleabilidad, para la sociedad a ciudadanos respetables y competentes (Lamarra, 2006). Así mismo, la calidad remite a cualidades siempre "en proceso de construcción..., no se puede reducirla solamente a sus recursos y productos más visibles y cuantificables, ellos expresan y manifiestan procesos educativos de calidad, mas no son la calidad en sí" (ASCUN, 1996, párr. 1).

Al hacer mención al concepto de la calidad educativa, según el Consejo Nacional de Acreditación - CNA (2016), el término se refiere a una serie de esfuerzos por parte de las instituciones por cumplir con las exigencias propias de cada una de sus funciones; por su parte el Ministerio de Educación Nacional - MEN (2016), define la calidad como aquella que forma mejores seres humanos, y para ello, propende por el fortalecimiento de procesos de evaluación y autoevaluación a la oferta educativa, a fin de responder a las necesidad del capital humano.

Desde la anterior perspectiva, existen diferentes hipótesis que en principio están interrelacionadas y que de su comprobación generarían insumos fundamentales para resolver los diferentes aspectos relacionados con la educación de largo plazo: i) las instituciones de educación acreditadas presentan un mejor desempeño en términos de calidad; ii) las instituciones de educación con unas mayores capacidades en recurso humano (nivel de formación, dedicación, retribución e incentivos, entre otros) en sus diferentes estructuras evidencian un mejor desempeño en los diferentes indicadores, no importando sus niveles de agregación; iii) la inversión en investigación y desarrollo $(\mathrm{I}+\mathrm{D})$, actividades de ciencia tecnología e innovación (ACTI) y los resultados de investigación de dichas instituciones presentan una relación directa con los resultados y las señales enviadas al mercado de calidad. Cada una de estas hipótesis se deben revisar y contrastar con la evidencia explícita reciente para determinar las diferentes alternativas en los mundos posibles de la generación de conocimiento con calidad.

Esta nueva edición de la Revista CIFE: Lecturas de Economía Social, interpreta el quehacer de la investigación desde diferentes enfoques, revitalizando los aspectos de la economía 
social. El investigador Nicolás Ronderos Pulido en su artículo titulado "Variaciones previsibles del ingreso y su efecto sobre el consumo. Un análisis para la economía colombiana", explica desde una perspectiva cuantitativa los determinantes del consumo de los hogares, el autor implementa un modelo $\operatorname{VAR}(\mathrm{p})$ encontrando evidencia a favor de la relación entre el ingreso previsible hacia el consumo de los hogares, desde este hallazgo se apoya la hipótesis de exceso de sensibilidad del consumo. Sagar Hernández continúa con su análisis teórico que complementa sus trabajos previos publicados en esta revista con su trabajo de investigación titulado "La fundamental convergencia teórica entre el pensamiento económico de la escuela monetarista de Chicago y el de los sociólogos constructivistas moderados: agente individual, organizaciones e instituciones". Los autores estudiados a lo largo del artículo muestran en su particular análisis que el modelo formal maximizador de agente presenta una racionalidad limitada, operando en entornos de información imperfecta, imputa costes a su proceso de toma de decisiones y desarrolla expectativas racionales. En relación con las organizaciones, examina la interacción entre formas de propiedad y gestión en las empresas, como mecanismos de reducción de la incertidumbre, considerando la división del trabajo como un principio fundamental de su funcionamiento, se afirma que las instituciones como fenómenos generales, naturales son potencialmente conflictivas.

Lorena Parada Parra, en su artículo titulado "Políticas y programas de estado para la salud rural en América Latina: una revisión de la literatura", determina cómo las políticas públicas en el tema de la salud, particularmente en lo rural, ha evolucionado a lo largo de los últimos años. La revisión de la literatura realizada establece que existen diversos programas que dan respuesta parcial a los problemas de salud existentes en las zonas rurales. En referencia a los programas de fomento rural en América Latina, la mayor parte son programas de lucha contra la pobreza y sus efectos han sido marginales.

Carlos Mario Londoño Toro en su artículo "Caracterización de los negocios barriales en los barrios del borde oriental de la comuna 10 de Medellín”, analiza la caracterización socioeconómica de los negocios en la comuna 10 de Medellín, concluyendo que los negocios barriales más representativos son aquellos que proveen bienes y servicios básicos para los hogares, son negocios que tienen debilidades estructurales relacionadas con la escasa oferta comercial, baja capacidad de generar ingresos, tamaño reducido y operación bajo grados de informalidad relativamente altos.

Mario Fernando Prieto Delgadillo y María Cristina Chinchilla Mora, desde la perspectiva microeconómica y la aplicación en la estructura de mercados, en su artículo denominado "El comportamiento del consumidor de las plazas de mercado de Villavicencio, Meta", determinan que las plazas de mercado son una institución fundamental en la sociedad, se encuentran diversos productos, satisfacen las necesidad básicas de la población y los bajos precios y no riñen con la calidad de los productos; la economía campesina es un eje fundamental del desarrollo local. 
Finalmente, el trabajo titulado, "Caracterización de la agroindustria artesanal y atributos de valoración en consumidores de queso bola de Ocosingo, Chiapas", del investigador Anastacio Espejel García, determina que las innovaciones son elementos centrales para la estandarización de los procesos, la utilidad y estrategia comercial son variables que impactan y generan mayores ganancias en este tipo de mercados.

Con esta nueva publicación esperamos seguir contribuyendo con la investigación en temas aplicados con sus respectivos efectos en lo local, regional, nacional e internacional, para seguir siendo un referente en los temas de la economía social.

\section{Referencias}

Asociación Colombiana de Universidades - ASGUN. (1996). Hacia una universidad autorregulada. Colombia: Documento de referencia para las universidades.

Consejo Nacional de Acreditación - CNA. (2016). ¿Qué significa calidad en la educación superior? ¿ C'ómo se determina? Recuperado de http://www.cna.gov.co/1741/article-187264. htm

Lamarra, N. F. (2006). La evaluación y la acreditación de la calidad: situación, tendencias y perspectivas. Informe sobre la educación superior en América Latina y el Caribe: la metamorfosis de la educación superior.

Ministerio de Educación Nacional - MEN. (2016). Fomento al mejoramiento de la calidad. Recuperado de http://www.mineducacion.gov.co/1759/w3-article-307590.html 


\title{
Editorial
}

\author{
Alexander Cotte Poveda* \\ Editor Revista CIFE \\ Universidad Santo Tomás
}

\section{Institutions and quality of education}

The importance of institutions and the quality of education are core elements in the assessment of knowledge and skills acquired by human capital in its different forms of expression. The quality of education is intimately related to the institutional framework and the established rules, relevant information to determine the competences reached during the schooling process. In this sense, the criteria, the assessment, the performance, the results, the productivity and the impact of another series of variables have effects that are manifested in the generation of knowledge and the responsibilities that education has as a public good with quality in the society.

One of the relevant questions is intimately related to the following idea: What are the quality criteria in education that determine the performance of that human capital formed over time? The importance of this question lies in the fact that it allows to determine and analyze the factors that affect the quality of education, its possible answers can

* Editor of the journal Revista CIFE: Lecturas de Economía Social, of the Santo Tomás University, Faculty of Economics. Mailing address: Facultad de Economía, Universidad Santo Tomás, carrera 9 n. 51 -11, piso 3, Bogotá, Colombia. Emails: alexandercotte@usantotomas.edu.co and revicife@usantotomas.edu.co 
allow to strengthen academic processes and enhance results, from differentiated strategies, but focused on the quality of teaching-learning. The knowledge of the factors that affect performance and quality among other variables enable the generation of relevant knowledge for policy decision making in education, improving teaching and academic practices and promoting greater equality in terms of learning in education systems and their institutionality.

The term quality is given according to the context in which it is used, and it is difficult to reach a consensus on the conceptualization of the term, for academics it refers to knowledge, for employers to competencies, for students to employability, for society to respectable and competent citizens (Lamarra, 2006). Likewise, quality refers to qualities that are always "in the process of being built..., it cannot be reduced only to its most visible and quantifiable resources and products, they express and manifest quality educational processes, but not quality itself" (ASCUN, 1996).

When mentioning the concept of educational quality, according to the National Accreditation Council - CNA (2016), the term refers to a series of efforts by institutions to comply with the requirements of each of their functions. For its part, the Ministry of National Education - MEN (2016), defines quality as that which forms better human beings, and for that purpose, strives for the strengthening of evaluation and self-evaluation processes of the educational offer, in order to respond to the needs of human capital.

From the previous perspective, there are different hypotheses that initially are interrelated and that from their verification would generate fundamental inputs to solve the different aspects related to long-term education: i) accredited educational institutions have a better performance in terms of quality; ii) educational institutions with greater capacities in human resources (training level, dedication, compensation and incentives, among others) in their different structures show a better performance in the different indicators, regardless of their levels of aggregation; iii) investment in research and development (R\&D), science, technology and innovation activities (STIA) and the research results of said institutions have a direct relationship with the results and signals sent to the quality market. Each of these hypotheses should be reviewed and contrasted with the recent explicit evidence to determine the different alternatives in the possible worlds of the generation of knowledge with quality.

This new edition of the journal Revista CIFE: Lecturas de Economía Social, interprets the task of research from different approaches, revitalizing the aspects of the social economy. Researcher Nicolás Ronderos Pulido in his article entitled "Predictable variations of income and its effect on consumption. An analysis for Colombian economy", explains from a quantitative perspective the determinants of household consumption, the author implements a $\operatorname{VAR}(\mathrm{p})$ model finding evidence in favor of the relationship 
between predictable income to household consumption, from this finding the hypothesis of excess sensitivity of consumption is supported. Sagar Hernández continues with his theoretical analysis that complements his previous works published in this journal with his research work entitled "The fundamental theoretical convergence between the economic thought of the Chicago monetarist school and that of the moderate constructivist sociologists: individual agent, organizations and institutions". The authors studied throughout the article show in their particular analysis that the formal maximizing agent model presents a limited rationality, operating in imperfect information environments, attributes costs to its decision making process and develops rational expectations. In relation to organizations, it examines the interaction between forms of ownership and management in companies, as mechanisms to reduce uncertainty, considering the division of labor as a fundamental principle of its operation, it affirms that institutions as general, natural phenomena are potentially conflicting.

Lorena Parada Parra, in her article entitled "State policies and programs for rural health in Latin America: a review of the literature", determines how public policies on health, particularly in rural areas, have evolved over the last years. The review of the literature establishes that there are several programs that partially respond to the health issues existing in rural areas. In reference to rural development programs in Latin America, most of them are anti-poverty programs and their effects have been marginal.

Carlos Mario Londoño Toro in his article "Characterization of the neighborhood businesses in eastern border neighborhoods of commune 10 of the city of Medellin", analyzes the socio-economic characterization of the businesses in commune 10 of Medellín, concluding that the most representative neighborhood businesses are those that provide basic goods and services for households, they are businesses that have structural weaknesses related to the limited commercial offer, low income generation capacity, small size and operation under relatively high levels of informality.

Mario Fernando Prieto Delgadillo and María Cristina Chinchilla Mora, from the microeconomic perspective and the application in the structure of markets, in their article called "Consumer behavior in the market squares of Villavicencio, Meta", establish that the market squares are a fundamental institution in society, they offer diverse products, satisfy the basic needs of the population and low prices and is not at odds with the quality of the products; the peasant economy is a fundamental axis of local development.

Finally, the work titled, "Characterization of artisanal agro-industry and valuation aspects in consumers of queso bola of Ocosingo, Chiapas", researcher Anastacio Espejel García, ascertains that innovations are essential elements for the standardization of 


\section{ČífFê 33}

processes, usefulness and commercial strategy are variables that impact and generate greater profits in these types of markets.

With this new publication, we hope to continue contributing to research on applied topics with their respective effects at local, regional, national and international levels, in order to continue being a benchmark in social economy issues.

\section{References}

Asociación Colombiana de Universidades - ASCUN. (1996). Hacia una universidad autorregulada. Colombia: Documento de referencia para las universidades.

Consejo Nacional de Acreditación - GNA. (2016). ¿Qué significa calidad en la educación superior? ¿Cómo se determina? Recuperado de http://www.cna.gov.co/1741/article-187264. $\underline{\mathrm{htm}}$

Lamarra, N. F. (2006). La evaluación y la acreditación de la calidad: situación, tendencias y perspectivas. Informe sobre la educación superior en América Latina y el Caribe: la metamorfosis de la educación superior.

Ministerio de Educación Nacional - MEN. (2016). Fomento al mejoramiento de la calidad. Recuperado de http://www.mineducacion.gov.co/1759/w3-article-307590.html 